\title{
Paradigm Shifts in Translation Studies: Focus on Linguistic, Cultural, Social and Psychological Turns
}

\author{
Hosni Mostafa El-daly \\ United Arab Emirates University, Al Ain, UAE
}

\begin{abstract}
Translation has been the subject of a variety of research and conflicts among theorists. This fact that gives Thomas Samuel Kuhn's paradigm theory is pertinent to the present study. Kuhn is an American philosopher of Science. In his book The Structure of Scientific Revolutions, he proposes his paradigm theory which plays a great role in the development of sociology and philosophy of Science. According to Kuhn (1970), paradigm originates from one or some famous people's achievements, and for these achievements to be considered as paradigms, two major characteristics must be met as will be clarified in this paper. This study is an attempt to outline the scope of the disciplines of Translation Studies (TS), to give some indication of the kind of work that has been done so far. It is an attempt to demonstrate that TS is a discipline in its own right. It is a vastly complex field with many far-reaching ramifications. This study discusses the relationships between the changing definitions of translation and the turns of translation studies.
\end{abstract}

Keywords: linguistic turn, cultural turn, social and psychological turn

\section{Introduction}

Throughout the recent history of translation studies, there are mainly three turns of translation studies: the linguistic turn, the cultural turn, and the social and psychological turn. It must be emphasized, here, that the changes of definitions and the turns of translation studies affect and contact each other closely. The definition of translation determines the scope of translation studies. A new definition that is widely accepted always generates a new turn and the new turn tends to breed a next new definition, and so on and so forth, hence the development of translation studies (Jixing, 2012, p. 35).

According to Thomas Kuhn (1970), a paradigm shift is a change in the basic assumptions or paradigms, within the ruling theory of science. A scientific revolution occurs, according to Kuhn, when scientists encounter anomalies that cannot be explained by the universally accepted paradigm within which scientific progress has been made. Kuhn argues that science does not progress via a linear accumulation of new knowledge, but undergoes periodic revolution in which the nature of scientific inquiry within a particular field is abruptly transformed. Kuhn defines a paradigm as an accepted model or pattern. It is a research mode or pattern which is concluded by a scientific group at a specific time, and in turn, guides their research. According to Kuhn, "a paradigm shift is a change from one way of thinking to another. It's a revolution, a transformation. It just does not happen, but rather it is driven by agents of change” (Kuhn, 1970, p. 10). In addition, a paradigm originates

Hosni Mostafa El-daly, associate professor, Ph.D., Department of Linguistics \& Applied Language Studies, College of Humanities and Social Sciences, United Arab Emirates University. 
from one or some famous people's achievements, and for these achievements to be considered as paradigm, two major characteristics must be satisfied: (1) The achievement is sufficiently unprecedented to attract an enduring group of adherents away from competing modes of scientific activity; (2) The achievement is sufficiently open-ended to leave all sorts of problems for the redefined group of practitioners to solve (Kuhn, 1970, p. 10).

According to Kuhn, when a new paradigm is formed, it gains its own new followers, and an intellectual "battle" takes place between the followers of the new paradigm and the hold-outs of the old paradigm. Kuhn denies the view that all kinds of belief systems are equal and states that when a scientific paradigm is replaced by a new one, the new one is always better, not just different. Finally, Kuhn has pointed out that the theory of paradigm shift is appropriate for humanities and social sciences. However, in social science, different paradigms can coexist, whereas in natural science, the old paradigm will be replaced entirely by a new one.

\section{Preliminaries}

\section{Misconceptions Regarding Translation}

Translation is occasionally taken too lightly by some. However, translation is in fact a serious business that should be approached sensibly in order to avoid poor results. First, some people may, mistakenly, think that knowing a foreign language makes a translator. This is the most common translation misconception and the most damaging one. A translator must have in-depth understanding and knowledge of at least two languages: a foreign language and a mother tongue. A translator must be able to write well and have an excellent command of the nuances in language use. Language is not free of cultural influences. If the culture behind the language which is being translated is not appreciated, an accurate translation is extremely difficult (Tonkin \& Frank, 2010; Riley, 2007). Second, translation has been perceived as a secondary activity, as a "mechanical” rather than a "creative" process, within the competence of anyone with a basic grounding in a language other than his/her own (Bassnett, 1996). Folk notions might still at times claim that proficiency in two languages along with a couple of dictionaries are all that one needs to produce a translation (Edwards, 2009; Gregorious, 2011). Beyond the notion stressed by the narrowly linguistic approach, that translation involves the transfer of "meaning” contained in one set of language signs into another set of language signs through competent use of the dictionary and grammar, the process involves a whole set of extra-linguistic criteria. Sapir (1956) claims that language is a guide to social reality and that human beings are at the mercy of the language that has become the medium of expression for their society. Experience, he asserts, is largely determined by the language habits of the community, and each separate structure represents a separate reality: "No two languages are ever sufficiently similar to be considered as representing the same social reality. The worlds in which different societies live are distinct worlds, not merely the same world with different labels attached" (Sapir, 1956, p. 69).

Sapir's thesis, endorsed later by Benjamin Lee Whorf, is related to the view advanced by the Soviet semiotician, Lotman (1978), that language is a modelling system. Lotman declares as firmly as Sapir or Whorf that "No language can exist unless it is steeped in the context of culture; and no culture can exist which does not have at its center; the structure of natural language” (Lotman, 1978, p. 18). Language, then, is

the heart within the body of culture, and it is the interaction between the two that results in the continuation of life-energy. In the same way that the surgeon, operating on the heart, cannot neglect the body that surrounds it, so the translator treats the text in isolation from the culture at his peril. (Bassnett, 1996, p. 4) 
Translation is, as Quirk (1974) puts it, "one of the most difficult task that a writer can take upon himself” (Quirk, 1974, p. 12). The third misconception regarding translation is that translating is easy. Translation can be very intricate, complex, and arduous work. Having to simultaneously concentrate on two different texts is mentally exhausting. This is because a translator is continuously moving between two languages and mind frames. A translator must first read and register source information then mange to digest it and present it accurately in the target language. The fourth misconception is that computers can now do translation. No translation program can and ever will be able to take the place of a human translator. This is because computers do not understand what language is and how it is used. Computers may be able to translate simple one-dimensional sentences, but they will never be able to tackle the complexities within literature or technical texts. If the translation is to be accurate and professionally prepared and presented, then, an experienced translator is crucial. Bad translations lead to many problems including people misunderstanding texts which ultimately reflect poorly on a company or organization. "If you want your car fixed you take it to a mechanic, not a car salesman. He may know a bit about cars but not enough to address your problems properly" (Pyne, 2004).

On the other hand, translation study in English has devoted much time to the problem of finding a term to describe translation itself. Some scholars such as Savory (1957) define translation as an "art"; others, such as Jacobsen (1958) define it as a "craft"; while others, perhaps more sensibly, borrow from the German and describe it as a "science". Frenz (1961) claims that translation is neither a creative art nor an imitative art, but stands somewhere between the two. This emphasis on terminological debate in English points again to the problematic of English Translation Studies. At all events, the perusal of such a debate is purposeless and can only draw attention away from the central problem of finding a terminology that can be utilized in the systematic study of translation (Bassnett, 1996).

Moreover, because translation is perceived as an intrinsic part of the foreign language teaching process, it has rarely been studied for its own sake. The stress throughout is on an understanding the syntax of the language being studied and on using translation as a means of demonstrating that understanding. It is hardly surprising that such a restricted concept of translation goes hand in hand with the low status accorded to the translator and to distinctions usually being made between the writer and the translator to the detriment of the latter. Belloc (1931) summed up the problem of status and his words are still perfectly applicable today:

The art of translation is a subsidiary art and derivative. On this account it has never been granted the dignity of original work, and has suffered too much in the general judgment of letters. This natural underestimation of its value has had the bad practical effect of lowering the standard demanded, and in some periods has almost destroyed the art altogether. The corresponding misunderstanding of its character has added to its degradation: neither its importance nor its difficulty has been grasped. (Belloc, 1931, p. 32)

\section{Discussion}

\section{What is Translation?}

At the outset, it may be important to point out that translation has been defined in many ways, and every definition reflects the theoretical approach underpinning it. Shuttleworth and Cowie (1997) observe that throughout the history of research into translation, the phenomenon has been variously delimited by formal descriptions, echoing the frameworks of the scholars proposing them. For example, Bell (1991) starts with an informal definition of translation, which runs as follows: "the transformation of a text originally in one 
language into an equivalent text in a different language retaining, as far as is possible, the content of the message and the formal features and functional roles of the original text" (p. 21). At the beginning of the "scientific" (Newmark, 1981, p. 2) study of translation, Catford (1965) described it in these terms: [...] the replacement of textual material in one language (SL) by equivalent textual material in another language (TL).

Central to reflections on the nature of translation, the task of the translator has always been the question of the translator's responsibility towards the original. To what extent, scholars have been asking for hundreds of years, can the translator add to, omit from, or in any way alter the source text? Debates on this issue have given rise to much theorizing and are at the heart of the free/literal translation paradigm. In modem times, considerations of the relationship between translation and original have often focused on principles of "faithfulness" and "accuracy". While usually understood in widely diverse ways, faithfulness has assumed the status of an ethical responsibility, with translators in many countries required to take an oath to guarantee the accuracy and correctness of their work before being officially licensed to practice. Translators, thus, are expected to present their readers with an "accurate" picture of the original, without any "distortions", and without imposing their personal values, or those of their own culture, on the intellectual products of other nations. The French philosopher and writer "Gilles Menage" coined the phrase "les belles infidels" to suggest that translations, like women, can be either "faithful" or "beautiful" but not both. "Faithfulness" is the extent to which a translation accurately renders the meaning of the source text, without distortion. On the other hand, "transparency" is the extent to which a translation appears to a motive speaker of the target language to have originally been written in that language and conforms to its grammar, syntax, and idiom.

In recent years, however, challenges to the "transparency" principle have been mounted chiefly by postmodernist and postcolonial critics. The most widely circulated and influential of these challenges can be found in the work of Lawrence Venuti. Venuti has called attention to the ethnocentrism inherent in what he has termed "domesticating translation", which assimilates the foreign text to the values of the receiving culture to create an impression of a natural text, whose translator is invisible. Venuti equates domesticating translation with "ethnocentric violence", a violence which involves appropriating others and assimilating them into the target culture's worldview, "reducing if not simply excluding the very differences that translation is called on to convey" (Venuti, 2008, p. 16). Venuti also maintains that domesticating translation consolidates the power hierarchy that imposes hegemonic discourses on the target culture by conforming to its worldview. Venuti has recently refined his position on domesticating translation. While domestication as a practice is still generally denounced, Venuti introduces a new potential function for it. He conceives of the possibility of a "foreignizing fluency that produces the illusion of transparency and enables the translation to pass for an original composition" (Venuti, 2008, p. 267).

Hatim and Munday (2004) point out that we can analyze translation from two different perspectives: that of a "process", which refers to the activity of turning a ST into a TT in another language, and that of a "product”, i.e., the translated text. Long time ago, Mounin (1963), the French theorist perceives translation as a series of operations of which the starting point and the end product are significations and function within a given culture. In this regard, Bassnett (1996) points out that the emphasis always in translation is on the reader or listener and the translator must tackle the SL text in such a way that the TL version will correspond to the SL version. The nature of that correspondence may vary considerably, but the principle remains constant. To attempt to impose the value system of the SL culture onto the TL culture is dangerous ground. The translator cannot be the author of the SL text, but as the author of the TL text has a clear moral responsibility to the TL 
readers. In this regard, Levy (1963), cited in Holmes (1970) insisted that any contracting or omitting of difficult expressions in translating was immoral. The translator, he believed, had the responsibility of finding a solution to the most daunting of problems, and he declared that the functional view must be adopted with regard not only to meaning but also to style and form (Moruwamon \& Kolawole, 2007).

\section{The Development of Translation Studies}

Translation was initially studied as a linguistic phenomenon, as a process of meaning transfer via linguistic transcoding, and consequently, Translation Studies was conceived as a linguistic discipline. Attempts were made to develop a "science of translation" (Nida, 1964), or a linguistic theory of translation (Catford, 1965), whose aim was to give a precise description of the equivalence relations between signs and combinations of signs in the source language(SL) and the target language (TL). Over the following years, as Ulrych and Bosinelli emphasized, the ties between translation and linguistics got even stronger, thanks to the development within linguistics of new paradigms which considered "[...] language as a social phenomenon that takes place within specific cultural context, like discourse analysis, text linguistics sociolinguistics, and pragmatics" (Ulrych \& Bosinelli, 1999, p. 229).

Since the early 1960's significant changes have taken place in the field of Translation Studies, with the growing acceptance of the study of linguistics and stylistics within literary criticism. Since 1965, great progress has been made in Translation Studies. The work of scholars in the Netherlands, Czechoslovakia, the Soviet Union, German, and the United States seems to indicate the emergence of clearly defined schools of Translation Studies, which place their emphasis on different aspects of the whole vast field. Moreover, translation specialists have benefited a great deal from work in marginally related areas (Bassnett, 1996). Emerging in the 1970s, developing in the 1980s, and flourishing in the 1990s (Bassnett, 1999, p. 214), TS has evolved enormously in the past twenty years and is now in the process of consolidating. TS has gradually evolved into a disciplines in its own right, or rather, as said, into an "interdiscipline", which draws on a wide range of other discipline and hence could be effectively described as "a house of many room" (Hatim, 2001, p. 8).

One of the first moves towards interdecsiplinarity can be considered Snell-Hornby's (1988/1995) "integrated approach". The approach was meant to bridge the gap between linguistic and literary-oriented methods. Lefevere (1978) proposed that the name Translation Studies should be adopted for the discipline that concerns itself with the problems raised by the production and description of translation. The Routledge Encyclopedia of Translation Studies defines "Translation Studies" as "[...] the academic discipline which concerns itself with the study of translation” (Baker, 1992, p. 276). As Baker points out, although initially focusing on literary translation, TS "[...] is now understood to refer to the academic discipline concerned with the study of translation at large , including literary and nonliterary translation” (Baker, 1992, p. 277).

Hatim defines TS as the discipline "[...] which concerns itself with the theory and practice of translation" (Hatim, 2001, p. 3). The practice of translation without a theoretical background tends toward a purely subjective exercise. As Yallop (1987) reminds us, one of Halliday's main contributions to linguistics is his desire to build bridges between linguistic theory and professional practice. "When dealing with translation, we firmly believe that this need is even stronger. Proficiency in two languages, the source one and the target one, is obviously not sufficient to become a competent translator” (Manfredi, 2008, p. 38). 
Translation theory is relevant to translators' problems, and not only for academic purposes, but also to the practice of a professional translator, since it can "[...] offer a set of conceptual tools [that] can be thought of as aids for mental problem-solving” (Chesterman \& Wagner, 2002, p. 7). Theory and practice are linked, and are not in conflict. Understanding of the processes can only help in the production, and a theory of translation without a link to practice is simply an abstraction.

Moreover, as Bassnett (1996) points out, although Translation Studies covers such a wide field, it can be roughly divided into four general areas of interest, each with degree of overlap. Two are product-oriented, in that the emphasis is on the functional aspect of the TL text in relation to the SL text, and two of them are process-oriented, in that the emphasis is on analyzing what actually takes place during translation. Ulrych and Bosinelli (1999) argue that the term "multidiscipline" is the most apt in portraying the present state of translation studies since it underlines both its independent nature and its plurality of perspectives. Translation studies can in fact be viewed as a "metadiscipline" that is able to accommodate diverse disciplines with their specific theoretical and methodological frameworks and thus to comprehend areas focusing, for example, on linguistic aspects of translation, cultural studies aspects, literary aspects and so on. Their account of TS is akin to Hatim's view that "translating is a multi-faceted activity, and there is room for a variety of perspectives" (Hatim, 2001, p. 10). According to Snell-Hornby (2006a) [Translation Studies] opens up new perspectives from which other disciplines—or more especially the world around—might well benefit. It is concerned, not with languages, objects, or cultures as such, but with communication across cultures, which does not merely consist of the sum of all factors involved. And what is not yet adequately recognized is how translation (studies) could help us communicate better-a deficit that sometimes has disastrous results (Leeuwen, 2011; Hua, 2011; O’Keeffe \& Clancy, 2011).

\section{Translation Studies and Linguistics.}

Along with the conviction that a multifaceted phenomenon like translation needs to be informed by multidisciplinarity, Manfredi (2008) believes that, within this perspective, linguistics has much to offer the study of translation. Since linguistics deals with the study of language and how this works, and since the process of translation vitally entails language, the relevance of linguistics to translation should never be in doubt. But it must immediately be made clear that we are referring in particular to "[...] those branches of linguistics which are concerned with the [...] social aspects of language use” (Bell, 1991, p. 13) and which locate the ST and TT firmly within their cultural contexts.

Mounin (1963) acknowledges the great benefits that advances in linguistics have brought to Translation Studies; the development of structural linguistics, the work of Saussure, of Hjelmslev, and of the Moscow and Prague Linguistic Circles has been of great value, and the work of Chomsky and the transformational linguists has also had its impact, particularly with regard to the study of Semantics. Mounin feels that it is thanks to developments in contemporary linguistics that we can (and must) accept that: (1) Personal experience in its uniqueness is untranslatable. (2) In theory the base units of any two languages (e.g., phonemes, monemes, etc.) are not always comparable. (3) Communication is possible when account is taken of the respective situations of speaker and hearer, or author and translator. In other words, Mounin believes that linguistics demonstrates that translation is a dialectic process that can be accomplished with relative success:

Translation may always start with the clearest situations, the most concrete messages, the most elementary universals. But as it involves the consideration of a language in its entirety, together with its most subjective messages, through an examination of common situations and a multiplication of contacts that need clarifying, then there is no doubt that 
communication through translation can never be completely finished, which also demonstrates that it is never wholly impossible either. (Mounin , 1963, p. 4)

One of the first to propose that linguistics should affect the study of translation was Jakobson who, in 1959, affirmed: "Any comparison of two languages implies an examination of their mutual translatability; the widespread practice of interlingual communication, particularly translating activities, must be kept under constant scrutiny by linguistic science” (1959/2000, pp. 233-234). In 1965, Catford opened his, “A Linguistic Theory of Translation", with the following assertion: "Clearly, then, any theory of translation must draw upon a theory of language - a general linguistic theory” (Catford, 1965, p. 1). As Fawcett (1997) suggests, the link between linguistics and translation can be twofold. On one hand, the findings of linguistics can be applied to the practice of translation; on the other hand, it is possible to establish a linguistic theory of translation. Bell even argues that translation can be invaluable to linguistics: "[...] as a vehicle for testing theory and for investigating language use” (Bell, 1991, xvi). Fawcett’s view is that, without a grounding in linguistics, the translator is like "[...] somebody who is working with an incomplete toolkit” (Fawcett, 1997, foreword). Taylor affirms that "translation is undeniably a linguistic phenomenon, at least in part" (Taylor , 1998, p. 10).

In spite of all this, on many sides the relevance of linguistics to translation has also been critiqued, or worse, neglected. Bell (1991) showed his contempt for such a skeptical attitude. He finds it paradoxical that many translation theorists should make little systematic use of the techniques and insights offered by linguistics, but also that many linguists should have little or no interest in the theory of translation. In his view, if translation scholars do not draw heavily on linguistics, they can hardly move beyond a subjective and arbitrary evaluation of the products, i.e., translated texts, they are, in short, doomed to have no concern for the process. Similarly, Hatim (2001) warns against those introductory books on TS which tend to criticize the role of linguistics in the theory of translation and blame it for any, or all, failure in translation. However, despite this skepticism, a genuine interest in linguistics does continue to thrive in TS. Even though Snell-Horney takes her distance from it, recently TS seems to have been characterized by a new "linguistic turn" (Snell-Hornby, 2006b). Up to the end of the 1970s, as Snell-Hornby reports (1988), most linguistically-oriented theories were centered around the concept of equivalence.

As Leonardi (2000) points out, the difficulty in defining equivalence seems to result in the impossibility of having a universal approach to this notion. It is undoubtedly one of the most problematic and controversial areas in the field of translation theory. The term has caused, and it seems quite probable that it will continue to cause, heated debates within the field of translation studies. This term has been analyzed, evaluated, and extensively discussed from different points of view and has been approached from many different perspectives. The question of defining equivalence is being pursued by two lines of development in Translocation Studies. The first, rather predictably, lays an emphasis on the special problems of semantics and on the transfer of semantic content from SL to TL. With the second, which explores the question of equivalence of literary texts, the work of the Russian Formalists and the Prague Linguists, together with more recent developments in discourse analysis, have broadened the problem of equivalence in its application to the translation of such texts. Holmes (1988), for example, feels that the use of the term equivalence is "perverse", since to ask for sameness is to ask too much.

Jakobson's study of equivalence gave new impetus to the theoretical analysis of translation since he introduced the notion of "equivalence in difference". On the basis of his semiotic approach to language and his 
aphorism "there is no signatum without signum" (Jakobson, 1959, p. 232), he suggests three kinds of translation: (1) intralingual (within one language, i.e. rewording or paraphrase), (2) interlingual (between two languages), and (3) intersemiotic (between sign systems). Jakobson claims that, in the case of interlingual translation, the translator makes use of synonyms in order to get the ST message across. This means that in interlingual translations there is no full equivalence between code units. According to his theory, "translation involves two equivalent messages in two different codes” (Jakobson, 1959, p. 233). Jakobson goes on to say that from a grammatical point of view languages may differ from one another to a greater or lesser degree, but this does not mean that a translation cannot be possible. He acknowledges that "whenever there is deficiency, terminology may be qualified and amplified by loanwords or loan-translations, neologisms or semantic shifts, and finally, by circumlocutions" (Jakobson, 1959, p. 234). Nida (1964) argues that there are two types of equivalence, namely formal equivalence - which in the second edition by Nida and Tabler (1982) is referred to as formal correspondence-and dynamic equivalence. Formal correspondence "focuses attention on the message itself, in both form and content", unlike dynamic equivalence which is based upon "the principle of equivalent effect” (Nida, 1964, p. 159). In the second edition (1982) of their work, the two theorists provide a more detailed explanation of each type of equivalence. Formal correspondence consists of a TL item which represents the closest equivalent of a SL word or phrase. Nida and Taber make it clear that there are not always formal equivalents between language pairs. They, therefore, suggest that these formal equivalents should be used wherever possible if the translation aims at achieving formal rather than dynamic equivalence. The use of formal equivalents might at times have serious implications in the TT since the translation will not be easily understood by the target audience (Fawcett, 1997). Nida and Taber themselves assert that "typically, formal correspondence distorts the grammatical and stylistic patterns of the receptor language, and hence distorts the message, so as to cause the receptor to misunderstand or to labor unduly hard” (Nida \& Taber, 1982, p. 201). Dynamic equivalencies are defined as a translation principle according to which a translator seeks to translate the meaning of the original in such a way that the TL wording will trigger the same impact on the TC audience as the original wording did upon the ST audience. They argue that frequently, the form of the original text is changed; but as long as the change follows the rules of back transformation in the source language, of contextual consistency in the transfer, and of transformation in the receptor language, the message is preserved and the translation is faithful. (Nida \& Taber, 1982, p. 200)

Catford (1965) advocated a theory of translation based on equivalence. A central task of translation theory is that of "defining the nature and conditions of translation equivalence" (Catford, 1965, p. 21). Catford had a preference for a more linguistic-based approach to translation and this approach is based on the linguistic work of Firth and Halliday. His main contribution in the field of translation theory is the introduction of the concept of types and shifts of translation. Catford proposed very broad types of translation in terms of three criteria: (1). the extent of translation (full translation vs. partial translation), (2). the grammatical rank at which the translation equivalence is established (rank-bound translation vs. unbounded translation), and (3). the levels of language involved in translation (total translation vs. restricted translation). The second type of translation is the one that concerns the concept of equivalence. In rank-bound translation an equivalent is sought in the TL for each word, or for each morpheme encountered in the ST. In unbounded translation equivalences are not tied to a particular rank, and we may additionally find equivalence at sentence, clause, and other levels. Catford was very much criticized for his linguistic theory of translation. One of the most scathing criticisms came from Snell-Hornby (1988), who argued that Catford's definition of textual equivalence is "circular". She considers 
the concept of equivalence in translation as being an illusion. She asserts that the translation process cannot simply be reduced to a linguistic exercise, as claimed by Catford, since there are also other factors, such as textual, cultural, and situational aspects, which should be taken into consideration when translating. In other words, she does not believe that linguistics is the only discipline which enables people to carry out a translation, since translating involves different cultures and different situations at the same time, and they do not always match from one language to another.

House (1977) is in favor of semantic and pragmatic equivalence and argues that ST and TT should match one another in function. House suggests that it is possible to characterize the function of a text by determining the situational dimensions of the ST. According to her theory, every text is in itself is placed within a particular situation which has to be correctly identified and taken into account by the translator. She acknowledges that "a translation text should not only match its source text in function, but employ equivalent situational-dimensional means to achieve that function” (House, 1977, p. 49). Central to House's discussion is the concept of overt and covert translations. In an overt translation the TT audience is not directly addressed and there is therefore no need at all to attempt to recreate a "second original" since an overt translation "must overtly be a translation" (House, 1977, p. 189). By covert translation, on the other hand, is meant the production of a text which is functionally equivalent to the ST. House also argues that in this type of translation the ST "is not specifically addressed to a TC audience” (House, 1977, p. 194).

An extremely interesting discussion of the notion of equivalence can be found in Baker (1992) who seems to offer a more detailed list of conditions upon which the concept of equivalence can be defined. She explores the notion of equivalence at different levels, in relation to the translation process, including all different aspects of translation and hence putting together the linguistic and the communicative approach. She distinguishes between four types. The first is the equivalence that can appear at word level and above word level, when translating from one language into another. The second is grammatical equivalence, when referring to the diversity of grammatical categories across languages. She notes that grammatical rules may vary across languages and this may pose some problems in terms of finding a direct correspondence in the TL. In fact, she claims that different grammatical structures in the SL and TL may cause remarkable changes in the way the information or message is carried across. These changes may induce the translator either to add or to omit information in the TT because of the lack of particular grammatical devices in the TL itself. The third is textual equivalence, when referring to the equivalence between a SL text and a TL text in terms of information and cohesion. Texture is a very important feature in translation since it provides useful guidelines for the comprehension and analysis of the ST which can help the translator in his or her attempt to produce a cohesive and coherent text for the TC audience in a specific context. It is up to the translator to decide whether or not to maintain the cohesive ties as well as the coherence of the SL text. His or her decision will be guided by three main factors, that is, the target audience, the purpose of the translation and the text type. The fourth is Pragmatic equivalence, when referring to implicatures and strategies of avoidance during the translation process. Implicature is not about what is explicitly said but what is implied. Therefore, the translator needs to work out implied meanings in translation in order to get the ST message across. The role of the translator is to recreate the author's intention in another culture in such a way that enables the TC reader to understand it clearly (Nunan, 2011; Walker, 2011).

Baker (1992) recognized that equivalence "is influenced by a variety of linguistic and cultural factors and is therefore always relative” (Baker, 1992, p. 6). Similarly Ivir defended the concept of equivalence as relative 
and not absolute, being strictly connected to the context of situation of the text (Ivir, 1996, p. 44). Halliday (2001) who based his definition of translation on the notion of equivalence, has more recently reassessed the centrality of equivalence in translation quality and proposed categorization according to three parameters, i.e., "Stratification”, “Metafuncton” and "Rank” (Halliday, 2001, p. 15).

Vinay and Darbelnet (1995) view equivalence-oriented translation as a procedure which "replicates the same situation as in the original, whilst using completely different wording” (Vinay \& Darbelnet, 1995, P. 342). They also suggest that, if this procedure is applied during the translation process, it can maintain the stylistic impact of the SL text in the TL text. According to them, equivalence is, therefore, the ideal method when the translator has to deal with proverbs, idioms, clichés, nominal or adjectival phrases, and the onomatopoeia of animal sounds. With regard to equivalent expressions between language pairs, Vinay and Darbelnet claim that they are acceptable as long as they are listed in a bilingual dictionary as "full equivalents" (Vinay \& Darbelnet, 1995, P. 255). However, they note that glossaries and collections of idiomatic expressions "can never be exhaustive” (Vinay \& Darbelnet, 1995, P. 256). They also, argue that even if the semantic equivalent of an expression in the SL text is quoted in a dictionary or a glossary, it is not enough, and it does not guarantee a successful translation (Segalowitz, 2011).

To sum up, these theorists have studied equivalence in relation to the translation process, using different approaches, and have provided fruitful ideas for further study on this topic. These theories can be substantially divided into three main groups. In the first there are those translation scholars who are in favor of a linguistic approach to translation and who seem to forget that translation in itself is not merely a matter of linguistics. In fact, when a message is transferred from the SL to TL, the translator is also dealing with two different cultures at the same time. This particular aspect seems to have been taken into consideration by the second group of theorists who regard translation equivalence as being essentially a transfer of the message from the SC to the TC and a pragmatic/semantic or functionally oriented approach to translation. Finally, there are other translation scholars who seem to stand in the middle, such as Baker for instance, who claims that equivalence is used "for the sake of convenience-because most translators are used to it rather than because it has any theoretical status” (Kenny, 1998, p. 77).

In this regard, Bassnett (1996) argues that equivalence in translation, then, should not be approached as search for sameness, since sameness cannot even exist between two TL versions of the same text, let alone between the SL and the TL version. And, once the principle is accepted that sameness cannot exist between two languages, it becomes possible to approach the question of loss and gain in the translation process. It is again an indication of the low status of translation that so much time should have been spent on discussing what is lost in the transfer of a text from SL to TL whilst ignoring what can also be gained, for the translator can at times enrich or clarify the SL text as a direct result of the translation process. Moreover, what is often seen as "lost" from the SL context may be replaced in TL context. When difficulties are encountered by the translator, the whole issue of the translatability of the text is raised. Catford distinguishes two types of untranslatability, which he terms linguistic and culture. On the linguistic level, untranslatability occurs when there is no lexical or syntactical substitute in the TL for an SL item. Catford's category of linguistic untranslatability, is straightforward, but his second category is more problematic. Linguistic untranslatability, he argues, is due to differences in the SL and the TL, whereas cultural untranslatability is due to the absence in the TL culture of a relevant situational feature for the SL text. 


\section{Shift to Socioculturally Oriented Concept of Translation}

\section{Translation: Two Languages and Two Cultural Traditions}

"Translation is a kind of activity which inevitably involves at least two languages and two cultural traditions” (Toury, 1978, p. 200). As this statement implies, translators are permanently faced with the problem of how to treat the cultural aspects implicit in a source text (ST) and of finding the most appropriate technique of successfully conveying these aspects in the target language (TL). These problems may vary in scope depending on the cultural and linguistic gap between the two (or more) languages concerned (Nida, 1964, 130). Language and culture may, then, be seen as being closely related and both aspects must be considered for translation. The notion of culture is essential to considering the implications for translation and, despite the differences in opinion as to whether language is part of culture or not, the two notions appear to be inseparable. Lotman's theory states that "no language can exist unless it is steeped in the context of culture; and no culture can exist which does not have at its centre, the structure of natural language" (Lotman, 1978, pp. 211-232). Bassnett (1980) underlines the importance of this double consideration when translating by stating that language is "the heart within the body of culture" (Bassnett, 1980, pp. 13-14), the survival of both aspects being interdependent. Linguistic notions of transferring meaning are seen as being only part of the translation process; "a whole set of extra-linguistic criteria" must also be considered. As Bassnett further points out, "the translator must tackle the SL text in such a way that the TL version will correspond to the SL version... To attempt to impose the value system of the SL culture into the TL culture is dangerous ground” (Bassnett, 1980, p. 23). Thus, when translating, it is important to consider not only the lexical impact on the TL reader, but also the manner in which cultural aspects may be perceived and make translating decisions accordingly (Sebba, Mahootian, \& Johnson).

Accordingly, Modern Translation Studies is no longer concerned with examining whether a translation has been "faithful" to a source text. Instead, the focus is on social, cultural, and communicative practices, on the cultural and ideological significance of translating and of translations, on the external politics of translation, on the relationship between translation behaviour and socio-cultural factors. In other words, there is a general recognition of the complexity of the phenomenon of translation, an increased concentration on social causation and human agency, and a focus on effects rather than on internal structures. The object of research of Translation Studies is thus not language(s), as traditionally seen, but human activity in different cultural contexts. The applicability of traditional binary opposites (such as source language/text/culture and target language/text/culture, content vs. form, literal vs. free translation) is called into question, and they are replaced by less stable notions (such as hybrid text, hybrid cultures, space-in-between, and intercultural space). It is also widely accepted nowadays that Translation Studies is not a sub-discipline of applied linguistics or of comparative literature. However, since insights and methods from various other disciplines are of relevance for studying all aspects of translation as product and process, Translation Studies is often characterised as an interdiscipline (Snell-Hornby, Pochhacker, Franz, \& Kaindl, 1992). In other words, translation itself being a crossroads of processes, products, functions, and agents, its description and explanation calls for a comprehensive interdisciplinary approach.

Since translation involves texts with a specific communicative function, the limitations of a narrow linguistic approach soon became obvious. Thus, from the 1970s, insights and approaches of text linguistics, pragmatics, discourse analysis, sociolinguistics, and communication studies, were adopted to translation studies. 
Translation was defined as text production, as retextualising a SL-text according to the TL conventions. The text moved into the centre of attention, and notions such as textuality, context, culture, communicative intention, function, text type, genre, and genre conventions have had an impact on reflecting about translation. Texts are produced and received with a specific purpose, or function, in mind. This is the main argument underlying functionalist approaches to translation, initiated by Vermeer (1989) with his Skopos Theory.

As Robinson (2005) points out, it is probably safe to say that there has never been a time when the community of translators was unaware of cultural differences and their significance for translation. The more aware the translator can become of these differences, the better a translator will be. Nevertheless, Manfredi (2008) argues that taking account of culture does not necessarily mean having to dismiss any kind of linguistic approach to translation. As we have seen, even from a linguistic point of view, language and culture are inextricably connected. Moreover, as House clearly (2002) states, if we opt for contextually-oriented linguistic approaches_-which see language as a social phenomenon embedded in culture and view the properly understood meaning of any linguistic item as requiring reference to the cultural context, we can tackle translation from both a linguistic and cultural perspective: [...] while considering translation to be a particular type of culturally determined practice, [to] also hold that is, at its core, a predominantly linguistic procedure (House, 2002, p. 93).

Culturally-oriented and linguistically-oriented approaches to translation " [...] are not, necessarily mutually exclusive alternatives” (Manfredi, 2007, p. 204). On the contrary, the inextricable link between language and culture can even be highlighted by a linguistic model that views language as a social phenomenon, indisputably embedded in culture. Chesterman (2006) does not support the linguistic-cultural studies divide that is typically used to categorize the shift or conflicting focus of research in Translation Studies. Chesterman considers that the growth in Translation Studies as an interdiscipline has led to fragmentation and that concepts and methodologies are "borrowed [from other disciplines] at a superficial level” which leads to "misunderstandings" since those working in Translation Studies are often lacking expertise in the other field and even borrowing concepts that may be outdated. This is an important criticism; Chesterman's solution is for collaborative work with scholars in other fields. Chesterman's proposal is for the adoption of the term "consilience”, which has its roots in the ancient Greek concept of the unity of knowledge and was recently revisited in the field of sociobiology by Edward Wilson. Consilience is relevant, in Chesterman's view, since "modem Translation Studies [...] announces itself as a new attempt to cut across boundaries in the search for a deeper understanding of the relations between texts, societies and cultures” (Chesterman, 2006, p. 25).

What has changed in recent translation scholarship on culture is an increasing emphasis on the collective control or shaping of cultural knowledge; the role played by ideology, or what Gramsci (1971) called "hegemony”, in constructing and maintaining cultural knowledge and policing transfers across cultural barriers. Beginning in the late 1970's, several groups of scholars began to explore the impact of cultural system on what gets translated, and why, and how, and how the translation is used. And beginning in the late 1980's, other group of scholars began to explore the ongoing impact of colonization on translation-especially the surviving power differentials between "first world" and "third world" countries and how they control the economics and ideology, and thus also the practice of translation (Robinson, 2005; Baker, 2006).

Pym (1992) attempted to define a culture as follows:

How might one define the points where one culture stops and another begins? The borders are no easier to draw than 
those between language and communities. It is enough to define the limits of a culture as the points where transferred texts have had to be (intralingually or interlingually) translated. That is, if a text can adequately be transferred [moved in space and 'or time] without translation there is cultural continuity. And if a text has been translated, it represents distance between at least two cultures. (Pym, 1992, p. 25)

In this regard, Robinson (2005) argues that texts move in space (are carried, mailed, faxed, and e-mailed) or in time (are physically preserved for later generations, who may use the language in which they were written in significantly different ways). Cultural difference is largely a function of the distance they move, the distance from the place or time in which they are written to the place or time in which they are read; and it can be marked by the act or fact of translation. As we approach cultural boundaries, transferred texts become increasingly difficult to understand, until we give up and demand a translation — and it is at the point, Pym suggests, that we know we have moved from one culture to another.

\section{Postcolonial Translation Studies}

Post-colonialism is one of the most thriving points of contact between Cultural Studies and Translation Studies. It can be defined as a broad cultural approach to the study of power relations between different groups, cultures, or peoples in which language, literature, and translation may play a role. Spivak's work is indicative of how cultural studies and especially post-colonialism has over the past decade focused on issues of translation, the translational and colonization. The linking of colonization and translation is accompanied by the argument that translation has played an active role in the colonization process and in disseminating an ideologically motivated image of colonized people. The metaphor has been used of the colony as an imitative and inferior translational copy whose suppressed identity has been overwritten by the colonizer. The postcolonial concepts may have conveyed a view of translation as just a damaging instrument of the colonizers who imposed their language and used translation to construct a distorted image of the suppressed people which served to reinforce the hierarchal structure of the colony. However, some critics of post-colonialism, like Robinson (1997), believe that the view of the translation as purely harmful and pernicious tool of the empire is inaccurate.

One theorist who has paid attention to the project of translation in the context of post-colonialism is Gayatri Spivak. Spivak describes her translating method as follows: First, the translator must surrender to the text. She must "solicit the text to show the limits of its language, because that rhetorical aspect will point at the silence of the absolute fraying of language that the text wards off, in its special manner” (Spivak, 1992, p. 181). The translator must earn the right to intimacy with the text, through the act of reading. Only then can she surrender to the text. Spivak herself practices total surrender by providing a first translation at top speed. Surrender at that point mainly means being literal. The revision is not in terms of a possible audience but "in a sort of English”, working against the text as “just a purveyor of social realism” (Spivak, 1992, p. 188). Spivak sees no reason why translation has to be a slow and time-consuming affair. If the translator is prepared and possesses the necessary reading skills, the sheer material production could be very quick.

\section{Social and Psychological Paradigm}

Social and psychological turn is the future developing trend of translation studies. In the book Translation and Identity in the Americans: New Directions in Translation Theory, Edwin Gentzler proposes that "the next turn in translation studies should be a social-psychological one, expanding a functional approach to include social effects and individual effects” (Gentzler, 2008, p. 180). As the name implies, social, and psychological turn has close relation with the study of psychology and sociology. The introduction of psychoanalysis plays a 
great role for translation studies. It is mainly based on the theory of Jean Laplanche, Sigmund Freud, and Jacques Lacan, the last two of which are especially influential. Freud believes that the mental condition of human being is composed of three stages, id, ego, and superego. Only if we keep the three ones in balance can we maintain health. In most cases, our neurosis owes to the repression of id and we usually translate our mental condition into dream. Lacan associates Freud's theory with language study. He regards unconsciousness as the essence of language and points out that the nature of human being is unconsciousness. Both Freud's and Lacan's theory show a close connection between the formation and identity. Since our mental condition now is influenced by the memory of past, psychoanalysts usually try to recreate the sights of the past so as to find out the specific demand which is repressed. "With a psychoanalytic reworking of an event, through the process of transference, an alternative translation is possible, one that is less repressive and more therapeutic" (Gentzler, 2008, p. 184). Based on the studies in the United States, Canada, Brazil, Latin America, and Caribbean, Gentzler proposes that it is translation that forms people's identity in the Americas.

As Gentzler defining translation as a social and psychological activity which forms the identity of a nation, translation studies are stepping into a new paradigm...social and psychological paradigm. The shift of paradigms again broadens the scope of translation studies. As the focus transfers from text to mind, this time, the scope includes not only language, context, but also the inside world of human being. With the broadening of the scope, translation studies will usher in a new turn-the social and psychological turn.

The definition of translation in social and psychological paradigm of translation studies not only considers the linguistic and cultural aspects of translation, but also introduces psychology into translation studies. From Edwin Gentzler's point of view, it is translation that constructs us; it is translation that forms our identity. Based on the studies of the situation of translation in various areas such as the United States, Canada, Brazil, Latin America, and Carribean, Gentzler connects the progress of human history with translation and puts forward the history of translation in the Americas is a history of identity formation. Translation, in his eyes, is a creative activity, not merely a linguistic operation, but one of the means by which an entire continent defines itself. In this regard, Gentzler agrees with Sherry Simon's definitions of translation: writing that is inspired by the encounter with other tongues, including the effects of creative interference (Jixing, 2012).

As Kassymova (2014) points out, the study of translation/interpretation from a psychological point of view allows considering this object (translation) more widely than it was done only from the points of linguistics and literary issues. Relatedly, both Pym (1992) and Zimnyaya (1993) agree that the presence of different approaches to translation are explained by understanding translation as a process and product, according to which there are two points of view: external and internal. As Zimnyaya (1993) explains, translation is a text from the perspective of "external knowledge" but an activity (aiming at the production of a text) from the perspective of "internal knowledge". The more complicated one is evidently the second point of view, "internal knowledge", because it is really difficult and sometimes impossible to have a deep insight into the mind of translators during the process of translation/interpretation. The mind of the translator has always been the black box that has not been included or at least not actively mapped.

\section{Conclusion}

Although most scholars today do agree that Translation Studies is not a sub-discipline of (applied) linguistics, the questions "where do we stand?" and "where do we go?” are being discussed more and more vigorously. Translation Studies continuously brings new theoretical developments to bear upon its disciplinary 
object. What is obvious in the substantially growing literature is that scholars have come to translation (studies) from a variety of fields and disciplinary backgrounds, whereas traditionally this background was linguistics (or its sub-disciplines, particularly pragmatics, text linguistics), and also literature. Nowadays there is an increasing input from Cultural Studies. One of the consequences is terminological inconsistency (Schaffner, 1999). When we take concepts from different disciplines we should clearly define them and clarify their disciplinary origin. It seems to be a general phenomenon that different academic disciplines use the same labels, however, with different meanings.

The preceding discussion shows that different paradigms of translation studies have different views on translation. As Jixing (2012) has maintained, the shifts of the paradigms can be viewed as the results of the development of definitions.

From a pedagogical perspective, the question that arises from the preceding discussion is that how translation courses should be designed and organized so that they would offer the students exactly what they need for their prospective career. This question implies that the task of the translation teacher does not consist only in developing in their students those skills which underlie the general translation competence, but also in creating a psychological climate which is very likely to turn the educational process into a positive experience for future translators. In this regard, Cozma and Dejica-Cartis (2013) conducted a mini-research study in which students were asked to answer the following questions: (1) Which are their fears and worries related to a potential career as a translator? (2) What should a translator course cover in order to make them feel psychologically secure about being a translator?, and (3) What can the translation teacher do in order to help them in this respect ? . Analyzing the students' answers shows some helpful points. First, almost all the subjects mentioned that their greatest fear as trainee translators refers to the lack of familiarity with many of the specialized domains in which they might be expected to work in the future. Also, in close connection to such a fear, most of the students confessed that they expected their teachers to give them the opportunity of acquiring various specific skills and knowledge associated with their future profession. As one of the subjects stated, "the translation teacher should explain to us what it takes to be a good translator" (Cozma \& Dejica-Cartis, 2013, p. 896). Second, the above study revealed the students' need for an emotionally safe atmosphere during the training process. As they mentioned, "their worries and fears are more likely to be erased by a translator trainer who "builds and sustains optimism”, "who has an understanding attitude” (personal information). They, also, stated that "the teacher should be supportive, creative and focus on the weak points of the students, instead of following a strict, pre-set agenda” (Cozma \& Dejica-Cartis, 2013, p. 897). Accordingly, Cozma and Dejica-Cartis has made the following conclusion: "It seems, therefore, that students perceive their good training for the translation career as being dependent not only on the teacher's ability to develop their professional skills, but also on the emotional atmosphere created during the process of training” (Cozma \& Dejica-Cartis, 2013, p. 899).

\section{References}

Baker, M. (1992). In other words: A course book on translation. London \& New York: Routledge.

Baker, M. (2006). Translation and conflict. London \& New York: Routledge.

Bassenet, S., \& Lefevere, A. (Eds). (1990). Translation, history and culture. London: Printer.

Bassnett, S. (1980/1991/2002). Translation studies. London \& New York: Routledge.

Bassnett, S. (1996). Translation studies. London: Routledge.

Bell, R. T. (1991). Translation and translating: Theory and practice. London \& New York: Longman. 
Belloc, H. (1931). On translation. Oxford: The Clarendon Press.

Catford, J. C. (1965). A linguistic theory of translation: An essay on applied linguistics. London: Oxford University Press.

Chesterman, A., \& Wagner, E. (2002). Can theory help translators?. A dialogue between the ivory tower and the wordface. Manchester: St. Jerome Publishing.

Chesterman, A. (2006). Memes of translation: The spread of idea in translation theory. Amsterdam and Philadelphia: John Benjamins.

Chesterman, A., \& Arrojo, R. (2000). Shared ground in translation studies. Target 12(1), 151-160.

Cozma, M., \& Dejica-Cartis, D. (2013). A psychological approach to professional translator education. Procedia—social and behavioural science, 84, 895-899.

Cromon, M. (2006). Translation and identity. London \& New York: Routledge.

Edwards, J. (2009). Language and identity. Cambridge: Cambridge University Press.

Fawcett, P. (1997). Translation and language: Linguistic theories explained. Manchester: St Jerome Publishing.

Frenz, H. (1961). The Art of translation. In P. N. Stalknecht \& H. Frenz. (Eds.), Comparative literature: Method and perspective. Carbondale: Southern Illinois University Press.

Gentzler, E. (2008). Translation and identity in the Americans: New directions in translation studies. London \& New York: Routledge.

Gramsci, A. (1971). Selections from the prison notebooks. Q. Hoare \& N. G. Smith (Eds.). New York: International Publishers.

Gregorious, C. (2011). Language, ideology and identity in serial killer narrative. Routledge: Taylor \& Francis Group.

Halliday, M. A. K. (2001). Towards a theory of good translation (pp. 13-18). In E. Steiner \& C. Yallop (Eds.). The Hague: Mouton.

Hammerly, H. (1971). Recent methods and trends in second language teaching. The modern language journal, IV(8).

Hatim, B. ( 2001). Teaching and researching translation. Harlow: Pearson Education Limited.

Hatim, B., \& Munday, J. (2004). Translation: An advanced resource book. London \& New York: Routledge.

Hatim, B., \& Munday, J. (2006). Translation: An advanced resource book. London \& New York: Routledge.

Haycraft, J. (1979). An introduction to English language teaching. London: Longman.

Holmes, J. (1988). The nature of translation. The Hague: Mouton.

House, J. (2002). Universality versus culture specificity in translation. In A. Richardi (Ed.), Translation Studies: Perspectives on an Emerging Discipline (pp. 92-110). Cambridge: CUP.

House , J. (2006a). Communicative styles in English and German. European journal of English studies, (10), 249-267.

House , J. (2006b). Text and context in translation. Journal of pragmatics, 38, 338-358.

House, J. (2008). Beyond intervention: universals in translation. Trans-kom, (1), 6-19.

House J., Rosairo, M., Martin, B. (Eds.). (2005). Translation and the construction of identity (paper presented at International association for Translation and Intercultural Studies, Seoul, South Korea).

House, J. (1977). A model for translation quality assessment. Tübingen: Gunter Narr.

Hua, Z. ( 2011). The language and intercultural communication reader. Routledge: Taylor \& Francis Group.

Ivir, V. (1987). Procedure and strategies for the translation of culture. In G. Toury (Ed.), Indian Journal of Applied Linguistics (Special issue on Translation Across Cultures). 13(2), 35-46.

Ivir, V. (1996). A case for linguistics in translation theory. Target 8(1), 149-157.

Leeuwen, T. (2011). Introducing social semiotics. Routledge: Routledge Taylor \& Francis Group.

Levy, J. (1963). The art of translation. New York: Longman.

Jacobson, F. (1958). Translation: A traditional craft. Copenhagen: Nordisk Forlag.

Jakobson, R. (1959). On linguistic aspect of translation. In L. Venuti (Ed.), The translation studies reader (2004, 2nd ed.) (pp. 138-143). New York \& London: Routlegdge.

Jixing, L. (2012). Changes of translation definitions and turns of translation studies. Cross-Cultural Communication. 8(5), 35-4.

Kassymova, G. (2014). The problems of psychological training in the future translators/interpreters education. Procedia-Social and Behavioral Sciences, 114, 717-729.

Kenny, D. (1998). Equivalence. Cambridge: Cambridge University Press.

Kuhn, T. (1970). The structure of scientific revolutions. London: The University of Chicago Press, Ltd..

Lefevere, A. (1978). Translation studies: The goal of the discipline. In S. H. James, J. Lambert, \& R. van den Broeck (Eds.), Literature and translation. Louvain: ACCO.

Leonardi, V. (2000). Equivalence in translation: Between myth and reality. Translation Journal, 4(4). 
Lotman, J., \& Uspensky, B. (1978). On the semiotic mechanism of culture. New literary history, 211-32.

Manfredi, M. (2007). The issue of "visibility" in translating topography and the culture of London and Bombay/ Mumbai. In L. Jottini, G. Del Lungo, \& J. Douthwaite (Eds.). Cityscapes: Islands of the self. Language studies, 2, 203-214. Cagliari: CUEC.

Manfredi, M. (2008). Translating text and context: Translational studies and systematic. Functional Linguistics. Cagliari: CUEC.

Moruwawon, S., \& Kolawole, S. (2007). Critical approaches to the notion of translatability and untranslatability of texts in translation studies. Pakistan journal of social sciences, 4(3), 375-379.

Mounin, G. (1963). Les problèmesthéoriques de la traduction. Paris: Gallimard.

Newmark, P. (1988). A textbook of translation. New York/London/Toronto/Sydney: Prentice Hall.

Nida, E. (1964). Principle of correspondence. In L. Venuti (Ed.), The translation studies reader. London: Routledge.

Nida, E. A., \& Taber, R.C. (1969/1982). The theory and practice of translation. Leiden: E. J. Brill.

Nunan, D. (2011). Language and culture. Routledge : Taylor \& Francis Group.

O’Keeffe, A., \& Clancy, B. (2011). Introducing pragmatics in use. Routledge: Taylor \& Francis Group.

Poole, A., \& Sheorey, R. (2002). Sophisticated noticing: Examination of an Indian professional's use of English. Indian journal of applied linguistics, 28 (2), 121-136.

Pym, A., (1992). Translation and text transfer: an essay on the principle of intercultural communication. Frankfurt am Main: Peter Lang.

Pyne, N. (2004). Translation misconceptions. Retrieved from www. kwintessential.co.uk / translation/ translation.html

Quick, R. (1974). The linguistic and the English language. London: Edward Arnold.

Riley, P. (2007). Language, culture and identity. London: Continuum.

Robinson, D. (1997). Translation and empire: Postcolonial theories explained. Manchester, UK: St. Jerome.

Robinson, D. (2005). Becoming a translator: An Introduction to the theory and practice of translation. Routledge, London and New York: Taylor \& Francis Group.

Sapir, E. (1956). Culture, language and personality. Los Angeles: University of California Press.

Savory, T. (1957). The Art of Translation (London Cape). Amsterdam and Philadelphia: Benjamins.

Schaffner, C. (1999). Globalization, communication, translation. Current issues in language and society, 6(2).

Sebba, M., Mahootian, S., \& Johnson, C. (2011). Language mixing and code-switching in writing. Routledge: Taylor \& Francis Group.

Segalowitz, N. (2011). Cognitive bases of second language fluency. Routledge: Taylor \& Francis Group.

Shuttleworth, M., \& Cowie, M. (1997). Dictionary of translation studies. Manchester: St. Jerome.

Snell-Hornby, M. (1988). Translation studies: an integrated approach. Amsterdam/Philadelphia: Benjamins.

Snell-Hornby, M., Pochhacker, F., \& Kaindl, K. (Eds.). (1992). Translation studies. An interdiscipline. Amsterdam and Philadelphia: Benjamins.

Snell-Hornby, M. (1995). Translation studies: An integrated approach (revised edition). Amsterdam/Philadelphia, PA: John Benjamins.

Snell-Hornby, M. (2006a). The turns of translation studies: New paradigms or shifting viewpoints?. Amsterdam/Philadelphia: Benjamins.

Snell-Hornby, M. (2006b). The turns of translation studies: New paradigms or shifting viewpoints?. Benjamins Translation Library: John Benjamins.

Spivak, G. (1992). The politics of translation. In M. Barret \& A. Philips (Eds.), Destablizing theory: Contemporary feminist debates (pp. 177-200). Cambridge: Polity Press.

Taylor, C. (1998). Language to language. Cambridge: Cambridge University Press.

Tonkin, H., \& Frank, M. (2010). The translator as mediator of cultures. Amsterdam/Philadelphia: John Benjamins Publishing Company.

Toury, G. (1978/1995). The nature and role of norms in translation. In L. Venuti (Ed.), The translation studies reader. London: Routledge.

Ulrych, M., \& Bosinelli, R. M. (1999). The state of the art in translation studies: An overview. Textus, XII(2), $219-241$.

Venuti, L. (1992). Translation as cultural politics: Regimes of domestication in English. Textual practice, 7(2), 208-23.

Venuti, L. (1995/2008). The translator's invisibility: A history of translation (2nd ed.). London \& New York: Routledge.

Venuti, L. (1998). The scandals of translation: Towards on ethics of difference. London and New York: Routledge.

Vermeer, H. (1978/1989). Skopos and commision in translational activity. In L. Venuti (Ed.), The translation studies reader. London: Routledge. 
Vinay, J. P., \& Darbelnet, J. (1958/1995). Comparative stylistic of French and English: A methodology for translation. (J. C. Sager \& M. J. Hamel, Trans.). Hamel. Amsterdam / Philadelphia: John Benjamins.

Walker, J. (2011). Variation in linguistic systems. London\& New York: Routledge, Taylor \& Francis Group.

Yallop, C. (1987). The practice and theory of translation. In R. Steele \& T. T. Gold (Eds.), Language topics: Essays in honour of Michael Halliday, 1, 347-351. Amsterdam/ Philadelphia: John Benjamins.

Zimnyaya, I. (1993). A psychological analysis of translation as a type of speech activity. In P. Zlateva (Ed.), Translation as a social activity. Russian and Bulgarian Perspectives (pp. 87-100). New York: Routledge. 